と思ひますから其の限度迄凡ての塗粼の瞻蔽力を低下せ しめると云ふやり方だけでも相當に材料の節約となり必 要以上の原料の亂費を防ぐことが出來ると思ふ2。現在鼠

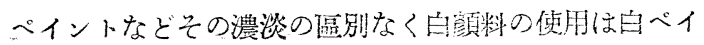
ントの $90 \%$ 以上と云ふ樣な梘格ではどうかと思はれる 䟴鼠色ペイントなどではもつともつと出異料が節約出來 るものである。

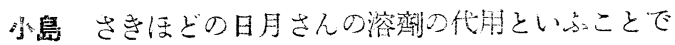

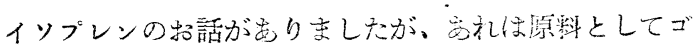
ムを花つたならといふ御見解でせらか。

日月今のところは天然樹脂の活朋坫議會といふるの がありまして、この方でダンマーがあるからダンマーを 乾溜して出來た油を酸化してやららかと考几て䧳ります

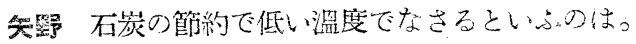

日月 それは高い溫度で焚きますと突の保温の翏係で 熱の損失があります低い㵋度でやりますと、時目的は長い が僅かの燃料で可能ですり且油の酸化するときの酸化熱
で殆ど然料を使朋せ㐫とも艮い事が判つてをり史す。

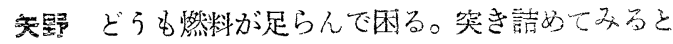

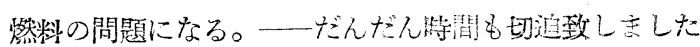

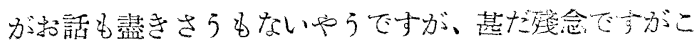
の邊で打切りたいと思ひます。皆樣の大變有急なる和話

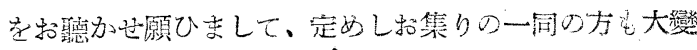
裨谷なさつたことと思ひきすす。この際一同の灰に代りま

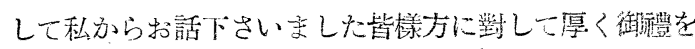
申上げてこの會を閉ぢをことに畋します。

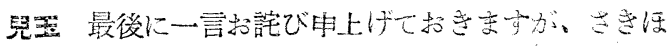
と軍需省の方からも御出席を願ふかけで敌迎へに上りま

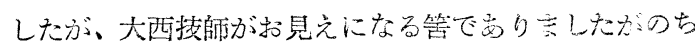
に行くからといふことで今までお街ちしてなりましたが

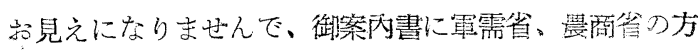
も見えるといふことを書いておきまして、洵に中㩐ない

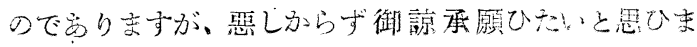
霡(了)

\title{
報

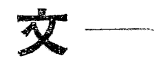 \\ 韵周波絕緣材料に就いて
}

住友電氣工策阵式會社硎究部長 中 谷信 吉

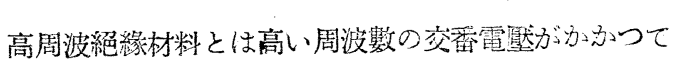
るるところ省絕緣するために使用せられる絕緣材粼で心 る。低周波と高周波との竟界は籼然としないが通常數萬 サイクル以上の所謂悡線周波の帶域を高周波と標する現 在の戰等に於て最も雷要なる新兵器として出現した電波 探知機の使用する周波數は超高周波或は極超高周波と言 ふ镁に止まるところを知ら程高くなりつつ家る狀態で ある。

長 波 $10,000 \sim 1,000 \mathrm{~m}(30 \sim 300 \mathrm{KC})$

中 波 $1,000 \sim 100 \mathrm{~m}(300 \sim 3000 \mathrm{KC})$

短 波 $100 \sim 10 \mathrm{~m}(3-30 \mathrm{MC})$

超短波 $10 \sim 1 \mathrm{~m}(30 \sim 300 \mathrm{MC})$

梗超短波

デシメーター波 100〜 $10 \mathrm{~cm}(300 \sim 3,000 \mathrm{MC})$

センチメーター波 10〜1 cm (3,000〜30,000MC).

ミリメーター波 $1 \sim 0.1 \mathrm{~cm}(30,000 \mathrm{MC})$

無線工學發達の初期に於ては絕緣材料として從來上り 使用せられてるたところの長石稀器、アルカリ确子、ゴ
ム、エボナイト、石炭酸樹脂、紙などがその㦈像用せら

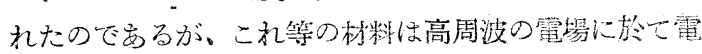
氣的エネルギー定吸收する性質が安るた絕緣が不良之

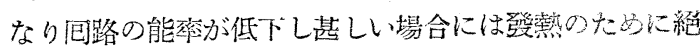
䋹物が炭化して破壤すると言ふ樣な結果に陷ることが解 つて來たので高周波に於て電氣的エネルギーを吸收する 度合の少ない絕緣物即ち誘電軆損失の小なる絕緮材翻が 必要となつたのである。このことは使用周枝數が高くな るに從つて一㾪痛切に感ぜられる譯である。

高楇波絕緣材料としては誘電體損失の优に誘雷荼の數 值如何がその高周波特性を決定する重要な瑟菜となる のであるがこれは用途によつて大なること在必琶とする 場合も㐫り、小なることを必要と寸る場合も焉る。高周 波絶線材料の用途を大别すると(イ) 蓄電器誘電滑豊とす

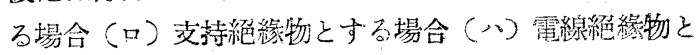
する場合の三つに大別ずることが出來る。この中(イ)の 場合は誘電率がなるべく大で岁ることを我要とし(口)の 場合は反對になるべく小であること妾必要とする。何れ 
の場合にも誘電體損失は小であることが望ましいのであ るが特に(ハ)の場合に於ては誘電體損失の値が決定的の 要素となるのである。

高周波用電線に要求せらるる電氣的特性の中最も重要 なる特性は特性インピーダンスが適當なる值をとること と減裏量が小なることである。

特性インピーダンスは主として電線の構造によつて決 定せらるる數值であつて例ば同軸型電線に在つては內部 導體の外俓 $d_{1}$ と外部導體の內鱼 $d_{2}$ との比によつて適 當に變化させることが出來るから所要の特性インピーダ ンスを與、るためには絕總材料の性質は山まり關係がな い。ところか減衰量は導體抵抗に上る減衰 $\beta_{r}$ と絕緣物 の誘電䚙損失による減衰 $\beta_{g}$ との和であり前者は $d_{2} / d_{1}$ が一定の場合 $\sqrt{ } f \cdot \sqrt{\varepsilon}$ に比例し $d_{2}$ に逆比例する。 後者は電線の構造に關係なく $\sqrt{\varepsilon} \cdot \tan \delta \cdot f$ に比例する $(f$ は周波數、 $\varepsilon$ は誘電率、 $\tan \delta$ は誘電體損失角) 即ち $\beta_{r}$ は周波數の平方根に比例し $\boldsymbol{\beta}_{g}$ は周波數に比例する。 一般に比較的低い周波數に於てほ $\boldsymbol{\beta}_{r}>\boldsymbol{\beta}_{g}$ であるが周波 數が高くなるに徎つて $\boldsymbol{\beta}_{g}$ の增大が顯著となるから透に は $\beta_{r}<\beta_{g}$ となる。超高周波或は橄超高周波に於ては $\tan \delta$ が極めて小たない限り $\boldsymbol{\beta}_{g}$ の值が致命的の大さと なるのでする。

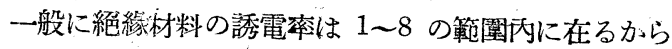
誘電家の值如何に上つて電線の特性が變化する程度は少 ないが誘電體損失角の值は材質によつて二桁も三桁も相 異するからその影響するところは大きい。

高周波に於る絕線轵の誘電體損失に關する理論は分子 構造諭並に原子物理學に關する多くの研究によつて次第 に明かにせられつつあるが具體的に如何なる材料が高周 波絕緣物として適當であるかと言ふと榓機材料としては 無水硅酸を主成分とするものであつて、しかもアルカリ 金屬を含有せざるもの、有機材料としては純粹の炭化水 素がよいとぜられてるる。その理由はアルカリ金屬の化 合物沈濕氣を吸收し易いから容易にイオンとなつて電昜 に應じて移動するものであり、また炭素結合を骨格とす る有機物の分子に水素以外の重い原子が附加せられてる るとその分子は始奶或る值の双概子能率を有するこ ととなり電場に應じて分子或は分子の枝が振動寸るから 何れの場合にも電氣的六ルギーが消耗せられて損失と なるのであると考つられる。

水晶、電母、硅矹酸硝子、ステアタイト磁器等の艋機 材料、ポリスタロールの如き有機材料が前述の條件に合 至するものでめり從つて優秀なる高周波絕緣材料である パラフインの如きものは䞍製せられた狀態に於ては誘電
體損失が植めて小であるが脆弱であり且つ熔融溫度が低 いために使用範園が著しく制限せられる或る程度の機械. 的强度並に耐熱性を保持するためには分子が大きいこと が必垽である。ゴムは天然座の炭化水素上り成る高分子 化合物であるが不純物を含有するために誘電體損失は大 きい。

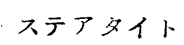

ステアタイトは滑石 (䂠酸マグネシゥム) を主成分と する磁器であつて約 30 年前獨逸に於て作られ高周波用 電線の絕緣物として實用せられた最初のものであるが現 在も佾無機質の高周波絕緣材料として最も重要なる地位 を占めてるる。我國に於ては始め無線機器製造業者が必 要に迫られて自家用としてこれの製造を開始したのであ るが最近は陶磁器製造業者も時局の影響をらけてステア タイトの製造を行ふ樣になつた。テイソン、タイデンタ イト、ゼッタイト、ーポライト等種々の商品名がある 製法は滑石粉末に酸化バリウム、酸化アルミニウム、酸 化鐵等の配合劑を加へ成型せる後 $1800 \sim 1500^{\circ} \mathrm{C}$ の高溫 に於て燒結する。これ等の酸合劑は燒結後の組織を緻望 にし吸水性を減ずることを目的とするものと考へられる 組成の一例は次の通りである。

$\begin{array}{lr}\mathrm{SiO}_{2} & 61.2 \% \\ \mathrm{MgO} & 30.7 \% \\ \mathrm{Al}_{2} \mathrm{O}_{3} & 2.9 \% \\ \mathrm{Fe}_{2} \mathrm{O}_{3} & 0.7 \% \\ \mathrm{BaO} & 4.5 \%\end{array}$

滑石の原鑛は滿洲國に良質のものが殆ど無畵藏に毞出 寸るから我國はステアタイトの原料には大に惠まれてる る譯である。

ステアダイトは比重 $2.6 \sim 2.8$ 抗張力 $5 \sim 19 \mathrm{~kg} / \mathrm{mm}^{2}$ 誘電率 6 損失角 3〜 $5 \times 10^{-4}$ であつて良質のものは一畵 夜浸水後も電氣的特性にあまり䛓化がない。

ステアタイトはその製泆からも明かな樣に高溫に耐へ ることが出來また機栈的强度も大であるが缺點としては 加工困難なること、吸濕性あること、正磪なる寸法のも のを得難きこと等が數へられる。ステアタイは燒結に際 して\%數の收縮を生ずるものであるがこの收縮は形狀、 大さ、溫度の不均一さ等に上つて程度を異にするから細 心の注意と熱練せる拔術を以てしても製品の寸泆を精笕 に揃へることは国雖でゅる。從つて寸法の許容誤差を極 めて小さくとらねばなら㨾な箅所には使用し難い。ま たステアタイトの吸濕性は我國の如き濕度の高い國に於 ては特に問題となるのであつて或は釉藥を施し或はパラ フインの如き防濕濟を含浸する等の對策を講ぜられてる 
るが何れもあまり効果はない樣である。結局素地その㒒 の狀態に於て吸濕し蜼いものが翟ましいので出つてこの 點萑試驗するため一書夜浸水後の損失的測定或はフクシ ン溶液による着色度觀察等が行はれてるる。高楇波絕緣 材料としてステアタイトは主として交持絕緣物に利朋せ られるが電線絕緣物として使朋する場合は圓板狀のもの を一定の間隔に弉着する方法或は四型のもの組合せて その背面にて外部導體支支持せしめる方法等がある。 テアタイトを使肘せる斯る棈造の電線は電氣的特性は良 好で女るが重量の大なること、可攃性不充分なること等 の缺點を衫しまた電線の徑が小となるに從つて製作工程 が非能率的となることを否れない。

ボリスチロール

スチロールが容易に重合して固罯となることは既に 1839 年 Simon によつて知られてるたのであるが電氣的 特性の優茄なることが注目せらるるに至つたのは比較的 近年のニとに屬する。1911年にはポリスチロールを電氣 絕緣用としてゴム、エボナイト、硝子等の代用とする英 國特許が岕るがこれは一向に實用化せられず 1928 年搬 邆用同軸型 フーブル並に長距離用海底電話ケーブルが發 達し始めた頃よりポリスチロールを電線絕緣材䊅として 應用しやらとする試みが行はれ始めた。そして約 10 年 以前に至つて電線のみならず篦電器、無線機器部分品等 あらゆる高度の絕緣在要とする簓所にポリスロールを 隹用することに關して多くの交擜が現はれる㦈になりま たそれまでは容易に人手することの出來なかつたポリス チロールも Trolitul. Rezoglaz, Victron 等の商品名の 下に次第に市場に出る樣になつたスチロール單量體は比 重 0.94 溜點 $14: 5^{\circ} \mathrm{C}$ の芳香を有寸る無色の液體で岕つて 水性瓦斯の中に可なり含有せられてるると言はれるがこ れを分離采取することは困難である。工栄的製法として はェチルベンゾールより出發する方法が最も多く行はれ てみる。印ちエチルベンゾールを直接脫水素する方法。

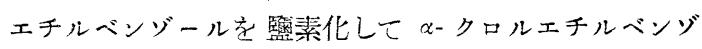
ールとしこれを脱監酸する方沠或は๙ークロルエチルベン ゾールを扣水分解してフェニルメチルカルビノルとして これ葆脫兆する方法等である。この他アセトフエノンを 經る方法、日ーフエニルエチルアルコホル女經る方法等が 岕る、日-フエニルエチルアルコホルを脫水すれば容易に 最も純粹なるスチロールが得られるので安るが $\beta$ ーフエニ ルエチルアルコホルは香水の一種であつて原價が高きに 過ざるとせられてるたが最近監對加工はこれの工業的慗 造に成功しスチロールの量座を實施してるる。

スチロールは熱によつて容易に重合するものためるが

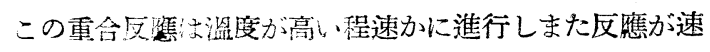
かである程生成物の重合度は低い:Schluzはこの重合反

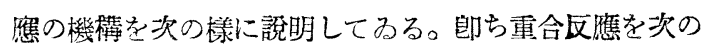
三つの獨立した反應に分割して考へる。

(a) 分子の活性化 $X \rightarrow X^{*}$

(b) 分子の生長 $X_{n} X^{*}+X \rightarrow X_{n+1} X^{*}$

(c) 分子の生長停止 $X_{n} X^{*}+X \rightarrow X_{n+2}$

(b) 皮び (c) の反應速度は (a) の夫れに比較して著し く大であるために全體としては(a) の反臀形式郎ち一分 子反隹の形式を示しまた生成する分子の長さは (b) と (c) との反應速度の比によつてのみ決定せられ (a) の反

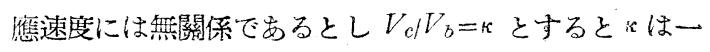
定の温度に於ては恒敖でり溫度の上昇につれて大とな 去。この假說に從ひこれを確萃の方則にあてはめて理論 的に薄いた生成物の重合度に關寸る分配曲線と實驗的に

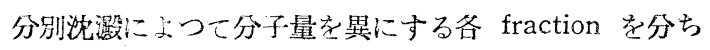
その實測分子量から求めた重合度分配曲線とはよく一致 ナる。

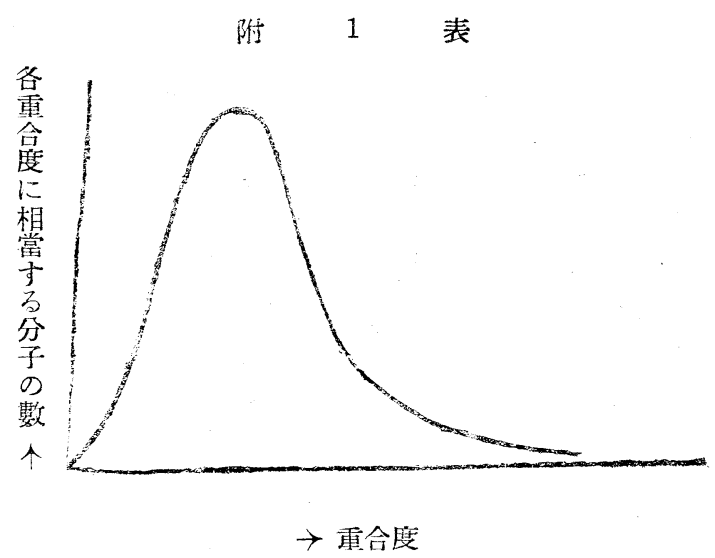

この分配曲線の最大點がその生成物の平均重合度に相 當しその值は1/浽等しいといふことになる。

重合に際して過酸化物の如き觸媒を使用すると重合速 度は增大するが生成物の重合度は矢坛り低下寸る。溶力 を以て稀釋した狀態に於て雷合を行ふと区應速度が小と なると共に然成物の重合度も低下寸る。

車合溫度と生成物の重合度との關係核次の如くなる。

\begin{tabular}{|c|c|c|c|}
\hline 重合溫度 & 重合時间 & 重合度 & \\
\hline 等溫 & 數十日 & $8000 \sim 10000$ & 粉粹困䧼 \\
\hline $100^{\circ} \mathrm{C}$ & 數日 & 2000 & 同 稍困難 \\
\hline $150^{\circ} \mathrm{C}$ & 10 時間 & 1000 & 可能 \\
\hline $200^{\circ} \mathrm{C}$ & 1 時間 & 500 & 同 容易 \\
\hline $250^{\circ} \mathrm{C}$ & 30分以內 & 100 & 脆弱 \\
\hline
\end{tabular}


ポリスチロールを加熱すると $80^{\circ} \mathrm{C}$ 前後より軟化し始 め $200^{\circ} \mathrm{C}$ 以上の溫度に於ては解重合の反應が顯著とな り $300^{\circ} \mathrm{C}$ 以上に至れば分解による煇發性物質の生成が 激增寸る。

ポリスチロールは無色透明の固體であるが室溫にて重 合せるものは極めて强䩲であり高溫軟化狀態に於てもゴ ム樣の彈性を呈するから流動性惡しく成型用として不適 當である。高溫に於て重合せるものは乾化狀態に於て彈 性索呈する溫度範園が猍く直ちに可塑性の狀態に移行す るから成型容易である。一般に $100^{\circ} \mathrm{C}$ 前後に於て豫備電 合を行ひ次で溫度を上昇して重合を完結せしめる方法が 行はれてるる。

ポリスチロールの成型は壓縮法或は注人法によつて行 はれるが所要成到溫度並に壓力は前者の場合 $120 \sim 180^{\circ} \mathrm{C}$ $20 \sim 130 \mathrm{~kg} / \mathrm{cm}^{2}$ 後者の場合 $190 \sim 220^{\circ} \mathrm{C}, 200 \sim 2000$ $\mathrm{kg} / \mathrm{cm}^{2}$ である。ポリスチロールはまた押出法によつて 紐或はテープとするこどが出來る。この場合分子の配列 如何が著しく製品の强度に影響を及ぼすから押出直後に 適當なる引伸し操作を施す必要がある。

ポリスチロールは芳香族炭化水素或は鹽素化せられた 炭化水素に溶解するから溶液より濕式法によつて糸或は 薄膜を作ることも出來る。この目的にはメチレンクロ イド、キシロール、イソプロピルベンゾール等の混合溶 劑が使用に適する。

絕緣塗料としても優秀であるがポリスチロールは光線 をよく透過せしめるから夜光塗料の展劑としても利用せ られる。ポリスチロールの吸水性は極めて少なく饱和吸 水量は $0.03 \%$ 程度であるが水分の透過度は比較的大き い從つて薄膜の防濕効果は充分でない。

ポリスチロール成型品は比重 1.05 抗張力 3 ～ $5 \mathrm{kgmm}^{2}$ で岕り注入洗による成型品の方が機械的强度は勝つてる るポリスチロール成型品は時日の經過につれて往ふにし て表面に白濁を生じ所謂失透現象を呈するがこれは主と して重合物中に殘存する單量體に基因するもので女る。 從つて成型前にポリスチロール粉末を高溫傎空處理に附 し揮發性物質を冭分に除去して置くことにより失透現象 を防止することが出來る。

ポリスチロールは誘電卒 2,5 損失角 $2 \sim 5 \times 10^{-4}$ 程度 であつてステアタイトと相並んで最も優秀なる高周波絕 緣材料の一つである。支持絕緣物としても使用世られる が軟化溫度が低いためにその使用範圍は著しく制限せら れる。電線絕緣物としてはスデアタトの場合と同樣に 圓板狀或は四型の成型品を使用することもあるが鐘型の 成型品を數珠慗ぎにする方式が最も多く行はれてるる。
この構造は可拄性に富もから徑の小なる電線にも好都合 である。獨逸に於てはこの大型の成型品を使用する構造 の他に螺旋狀に炝かれたポリスチロールのコルデルとテ 一プとを組合せた特殊の椿造の紛緣層を有する高周波用 電線も考案せられてみる。

ポリスチロールはステアタイトと比校して成型並に成 型後の加工が容易でありまた非吸濕性でもることは勝つ てるるが缺點は機械的强度が不充分であることと耐熱性 に格段の差異が岕ることである。マルテンス法によるボ リスチロールの而掕度は重合度によつて多少の相違は击 るが大體に於て $70 \sim 80^{\circ} \mathrm{C}$ 前後である。

ポリスチロールの耐熱性を向上せしめるために種々の 师究があるが末だ満足すべき成果は得られてるない。 Standinger は微量のデイヴイニイルベンジールをス ロールに加へて共重合せしめることにより鎖狀分子が連， 結せられて立體的構造を有するに至ることを發見した。 この場合生成物は溶劑に不溶性となるが軟化溫度には變 化が認められない、小田氏は $\beta$-ヴイニイルナフタリンと スチロールとの共重合物が軟化溫度高きことを報告して るるが高度の重合物が得難いために而掕性の向上は僅少 に止る樣である。

獨逸 I.G. 社の “Luvicxn” はヴイニイルカルバジル の重合物でありマルテンス法による耐熱度 $150^{\circ} \mathrm{C}$ のもの も得られたと發表せられてみるがポリスチロールと比較 して誘電體損失が可なり大きく且つ成型が困難でもる。 松井氏はスチロールの種々の誘導體を合成してその性能 を調べ p-クロルスチロール、m-アミノスチロール。m. シアンスチロール等が幾分軟化溫度の高いことを見出し たが矢張り純炭化水素でないために誘電體損失が大きい またポリスチロール粉末とステアタイト粉末とを適當に 配合して成型せる「陶試ライト」なるものは幾分軟化溫 度が高い樣であるが實用化せられるに至つてるない。

ステアタイト或はポリスチロールを絕緣物とする從來 の高周波用電線は前述の如く何れも內部に多くの空吵を 殘寸構造となつてるるが、これはステアタイト或はポり スチロールの如き柔軟性を有せざる硬質の材料を使用し しかも電線として必要なる可撓性を附與するためには已 を得ざる方式であるが一方に於ては空隚の多いことは實 効誘電體損失を少なくする意味に於ても好都合である 言ふことが出來る。しふっし斯の樣な内部に空吵の多い所 謂中空型電線は種々の缺陷を伴ふっものであつて即ち機㭜 的に棈造が不安定であること、損傷を受けた場合容易に 水或は濕氣が浸大し易いこと、耐電慰の低いこと、内部 構造が長さの方向に不均一であるから極めて短い波長に 
於て電实的反射を生ずる惧あること等がそれである。ま た雪線の製造工程から考へても多數の成型品表装着する

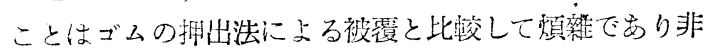
能率的である。從つて若し誘電䱏損失がステアタイイ或 はポリスチロールと同等程度に偉少でもつこしかもゴム 樣の柔乾性を有する材粗が得られたならばこれによつて ゴム被覆綛緣電線と同樣の構湟の所謂充筫型の高周波用 電線の製作が可能となり以上擧けな゙㮏な缺陷を除くこと が出來る譯である。亲りスチロールに唕當なる瑱化劑を 加へてゴム樣の柔軟性を附與しゃうと言ら試みも既に多 く研究せられてるるがポリスチロールの顿化温度を上昇

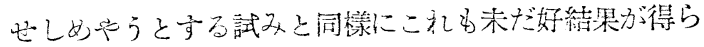
れるに至つてるない。ポリスチロールの電氣的特性を害

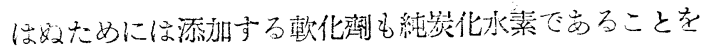
必要とすると共にポ》スチロールとの相溶性舆好なるこ と暉發性僅微なること等の称件が件ふから適當なる瑱化 劑の探求は容易でないと考へら礼る。從來提唱せられた そのにはスチロール低重合物、アミルナフタリン、ディ フェニル等沐㟧る。小田氏はエタン或はプロパンの兩端 にフェニル基芣有しそのフェニル基にブチル基或はアミ 几基の結合せるものがこの目的に副ふもので岁るとの見

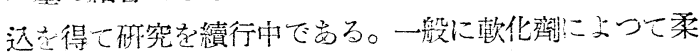
軟化せら机たポりスチロールは Cold flow 生ずる傾向 が萻しいからャング率の溫度による變化の少ないるのを 撰睪する必恶が岕る。

次に述べるポリイソブチレン立にポリエチレンは充賽

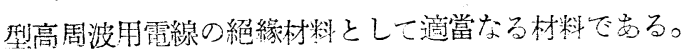

ポリイソブチレン

イソブチルアルコホルを脱承して得らるるイソブチレ ンは裳溫に於て氣體でするが極めて低い、溫度に於て監化 アルミニゥム或は弗化明素を镯媒として重合せしめると ゴム樣の重合物竟生成する。

獨逸 I.G, 社の “Oppanol” 米國スタンダードオイル 會社の“Vistanex”は何れも斯つ如き方法によつて作ら れたボイソブチレンであるとせられてるる。

“Oppanol” B-200 は分子量20曾で岀つてイソブチレ ン重合物として最も重合度の高い部類に屬寸る “"Oppanol" B-200 は比重 093 抗張力 $0.6 \mathrm{~kg} / \mathrm{mm}^{2}$ 白色牛透 明の彈性强きゴム樣物質である。化學藥品に對する抵抗 性に䁝夕天然ゴムの如き自然劣化の傾向なくまた耐水性 酎寒性等に勝孔てるるから紹總材料としてのみならず電 線の保護被㪇材料としても優秀なる材料でする。

誘霓率 2.3 , 誘電體損失はポリスチロールと比較して 幾分劣り䛈に高周波に於て少しく堙大寸る倾向がある。
最近の算逸製高周波用電線にはこの“Oppanol” B-200 と推定せらるる䋓緣物を以て充實型に作られたるのが見 受汁られる。

“Oppano!” B-200 は高溫に於ても彈性苂保持し容易 に可塑性となら妨から天然ゴムと此較して加工し難く壓 延口一儿、押出機等に特別の高溫裴置を必要とする。ま た斯の如く幧性が强いにも拘らず Cold flow 艾生ずる傾 向が岕る。

我或に於ては近年各所に於てポリイソブチレンの製造

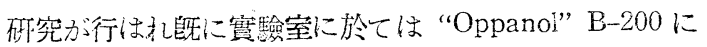
匹敵手高雷合䈨のものが得らるる樣になつてるるが未 だ工業的生产の域には澾してるない。イソブチレンの重 合反應は激弡的に蕉行し著しく發熱を件ふから裝置の容 量が堌大するに從つて反應の溫度を零下 $100^{\circ} \mathrm{C}$ 或は 120 “Cと言か樣な低溫に保つことが团難となつて來るので岁 る。この困難を克服するためイソブチレンを液化エチレ ンにて稀櫂しェチレンの蒸發潜熱によつて局部的溫度上

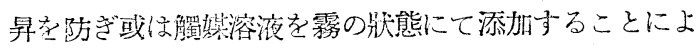
つて急激なる䨘合反應の隻行を綏和する方法などが外國 特許に見受けられる。

ポリエチレン

エチレンを䨘合して燃粼油或は潤滑油を得やうとする 㗏究は可なり以前より行はれてわたがエチレンを超高壓

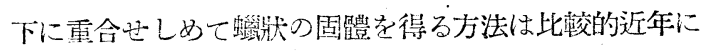
至つて知られ Fawcett その他の特許が岁る。即ちエチ レンを1000〜2000 氣壂に加厴しつつ 200〜300 $\mathrm{C}$ に加 熱するのであるがこの際微量の酸素の存在は重合反應を 著しく促進する。壓力の高い程また酸素量の少ない程生 成物の重合度は高い。

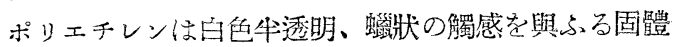
であつて比重 0.95 , 抗張力 $1.0 \mathrm{~kg} / \mathrm{mm}^{2}$ 前後を示し分 子量 10,000 以上のものは楅就强靫で岕つて反覆屈曲す るも容易に破碎しない。結晶性で山るから颠化温度範園 は比較的猍く $100 \sim 110^{\circ} \mathrm{C}$ に牛熔融狀態に移行する。 X線圖はパラフインと金く同一で岕る。

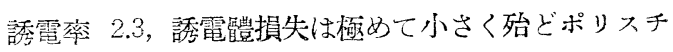
ロールと同一程度で要る。しかもポリイソブチレンの如 き Cold flow を生ずる倾向もないから充實型高周波用 電悢の絕緣材料としては現在のところ最も優秀なる材粼 ですると言ふことが出來る。

我國に於てポリエチレンの製造政究が開始せられたの は昨年以來のことであつて昭南島に於て占蒦せられた敵 の高周波用電線にこの材档が使用せられてあつたことに 端を發する。2000㴋壓と言ふ樣な高厴を必要とするため 
反應裝置の製作に種々の困難を件つたが現在各所に於る 研究は既に實驗室的過程を終了し工業的生產に移行しつ つある狀態であるからポリエチレンを使用せる充實型高
周波用電線が我國に於て實用化せられるのも近いことで あららと信ぜられる。

\section{木船船底塗料中の亞酸化銅の定量法に就て}

\section{1. 緒 言}

現在の木船船底浲料の試驗規格は塗料中の鍓の總量を 定量して之れを亞酸化銅に換算する方泆を探用してるる 昨年の10月中間に油脂統制會の濎本氏の御來訪受け此の 方面に就て種々談議せしに、同氏の言によれば從來の忩 規格を一部改正して新たに亞酸化銅定量の試驗項目を追 加して防污効果の少ない、銅鹽又は銅粉等の使用を極力避 けて木船船底塗料の品質を向上させたい。そして之れを 臨時日本標準規格として探用したいとの御希望であつた 故にこの實驗の目的は笴屈なる銅資源を最も効果的に使 用寸るにある。然し乍ら目下卧酸化銅の品質はその原料 及び副原料的に見てる低下を餘儀なくされつつある故に 現下の狀態より見て塗料原料としての 亞酸化銅は純度 $80 \%$ 以上酸化銅 $20 \%$ 以下のものを使用範圍と目的と した。

元より精確なる方法は期待難く縱へば精確なる方法を 假に立案したとしても實行に至難のものではその意義が ないので正磪度の點は幾分低下しても特別の裝置の要な く何處でも實施され易き方法を見出す可く實驗を進め た。

\section{2. 豫備試驗}

（1）醋酸及各種アンモニア監溶液に對する銅酸化物の 溶解試驗

先づ試驗管 $30 \mathrm{cc}$ に酸化銅及亞酸化銅の粉末の適量を

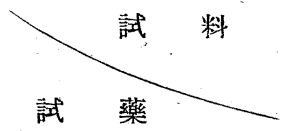

稀醋酸溶液

硫酸アンモン溶液

監化アンモン溶液

炭酸アンモニア液

アンモニア水

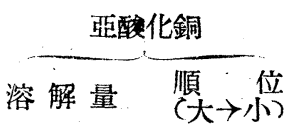

$\begin{array}{ll}\text { 少 量 } & 4 \\ \text { 少 量 } & 5 \text {; } \\ \text { 稍多量 } & 3 \\ \text { 稍多量 } & 2 \\ \text { 多量 } & 1\end{array}$

眞 野 惣治 郎
原

探り之れに醌酸及各種アンモニア監の溶液宛添加して二 種の銅酸化物る溶解する倾向を目擊した。

3 日經過後に於ける狀況は第 1 表の通りである。

上上の實驗に於て酸化銅より亞酸化銅を多く溶解与る ものは鹽化アンモン溶液とアンモニア水との二種である ことを知つた。

（2）供試原料の準備

本䔈驗に適當な品質と數量を調へ基礎試驗を行つた

1 亞酸化銅 三菱製品

口. 酸化銅 品質粗惡の亞酸化銅を灼䇥して製し た

、配合劑詢記の留酸化銅及酸化銅を $8: 2$ の 割合にて配合調製して 2 本實驗の原 料に供することにした

以上三種の原料の基碟試驗として亞酸化銅量及全銅量を 定量した

（イ）供試原料中の亞酸化銅の定量

試料 $0.25 \mathrm{~g}$ を有栓フラスコ $500 \mathrm{cc}$ に探り監化第二鐵 溶液（備考 1) $15 \mathrm{cc}$ を加へ完全に溶解せしめ(約 18 分を要した) 水 $200 \mathrm{cc}$ と燐酸 $5 \mathrm{cc}$ とを加へて $N / 10$ 過マンガン酸カリ液にて滴定した其の結果第 2 表の通り である。

亞酸化銅 及酸化銅 兩者の溶 解順位

(7)

(2)

\begin{tabular}{|c|c|}
\hline 溶 解'量 & 順 $\rightarrow$ 位 \\
\hline 稍多量 & 3 \\
\hline 少 量 & 5 \\
\hline 少 量 & 4 \\
\hline 稍多量 & 1 \\
\hline 多 量 & 2 \\
\hline
\end{tabular}

亞酸化銅 及酸化鉰 兩者の溶 解順位

(5) 